\title{
Separation and identification of celery proteins
}

\author{
Serena O'Neil", Katrin Darm, Laura Rethschulte, Allergy School Participants, Christian Scharf \\ From 5th International Symposium on Molecular Allergology (ISMA 2013) \\ Vienna, Austria. 6-7 December 2013
}

\section{Background}

Allergy to Apium graveolens is one of the more severe food allergies. Six celery allergens have been characterised, Api g 1-6, while additional allergens have characterised from other members of the Magnoliospida class, including kiwi, peanut and ragweed, suggesting homologous allergens may also be present in celery. The participants of the Omics Allergy School 2013 were provided with celery bulb and leaf extracts for two dimensional separation and immunoblotting.

\section{Methods}

Two dimensional electrophoresis was used to separate the bulb and stalk protein extracts of two strains of celery. Allergenic proteins were detected using sera from a celery allergic patient.

\section{Results}

Hundreds of celery bulb and stalk proteins were separated using $2 \mathrm{DE}$, using both silver stain and fluorescent labelling for increased sensitivity. The protein profile of two celery strains were distinctly different. A similar IgE binding pattern was observed to the bulb of the two strains of celery with 20-30 spots detected, while the binding pattern of the leaves of the two strains differed. Proteins have been identified by MALDI-ToF-MS/MS, with a de novo-sequencing approach used for protein identification due to limited protein sequences for celery. Post translational modifications of protein isoforms have been quantitatively labelled by $\mathrm{H} 216 \mathrm{O} / \mathrm{H} 218 \mathrm{O}$-trypsin and subsequently analysed by nanoLC-ESI-MS/MS. PNGase treatment has been used for addressing protein glycosylation.

\section{University of Medicine Greifswald, ENT Research Laboratory, Greifswald,} Germany

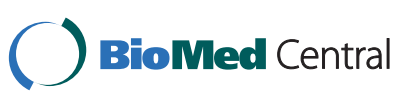

(c) 2014 O'Neil et al; licensee BioMed Central Ltd. This is an Open Access article distributed under the terms of the Creative Commons Attribution License (http://creativecommons.org/licenses/by/2.0), which permits unrestricted use, distribution, and reproduction in any medium, provided the original work is properly cited. The Creative Commons Public Domain Dedication waiver (http:// creativecommons.org/publicdomain/zero/1.0/) applies to the data made available in this article, unless otherwise stated. and take full advantage of:

- Convenient online submission

- Thorough peer review

- No space constraints or color figure charges

- Immediate publication on acceptance

- Inclusion in PubMed, CAS, Scopus and Google Scholar

- Research which is freely available for redistribution 